\title{
Role of Social Entrepreneurship in Supporting Business Opportunities and Entrepreneurship Competitiveness
}

\author{
P. Eko Prasetyo, Nurjannah Rahayu Kistanti \\ Department of Development Economics, Faculty of Economics, Universitas Negeri Semarang, Semarang, Indonesia \\ Email: pekoprasetyo@mail.unnes.ac.id,nurjannah.rk@mail.unnes.ac.id
}

How to cite this paper: Prasetyo, P. E., \& Kistanti, N. R. (2020). Role of Social Entrepreneurship in Supporting Business Opportunities and Entrepreneurship Competitiveness. Open Journal of Business and Management, 8, 1412-1425.

https://doi.org/10.4236/ojbm.2020.84090

Received: May 11, 2020

Accepted: June 14, 2020

Published: June 17, 2020

Copyright ( $\odot 2020$ by author(s) and Scientific Research Publishing Inc. This work is licensed under the Creative Commons Attribution International License (CC BY 4.0).

http://creativecommons.org/licenses/by/4.0/

\begin{abstract}
The negative impacts of Covid-19 pandemic are felt greater than the positive ones. These negative impacts may make settlement of main economic development problems in Indonesia more difficult. The purpose of this research is to explain the important role of social entrepreneurship factor in encouraging business opportunities which may then increase economic growth, sustainable competitiveness and prosperity. Achieving this explanation requires primary micro-fundamental data from home business players in DIY and Central Java provinces. For the explanation, it employs a multiple path analysis with correlational recursive model. The research result shows that social entrepreneurship factor is able to enhance the opportunities higher than human capital and new product factors. However, despite positive and significant, the role of social entrepreneurship and business opportunities in encouraging competitiveness is still low compared to the role of new product which may be produced and the role of key factor, human capital. The implication of the recommended policy is that it still requires economy regulation to encourage the role of social entrepreneurial culture more extensively and comprehensively.
\end{abstract}

\section{Keywords}

Social Entrepreneurship, Entrepreneurial Competitiveness, Economy Regulation

\section{Introduction}

There are three main problems of economic development that Indonesia finds it difficult to settle, namely unemployment, poverty and income inequality. The impacts of the spreading of Covid-19 (corona) disease, which is officially stated 
as a pandemic throughout the world by WHO, are severely suffered; not only in medical health and politics, but also economically and socially. Since pandemic is the highest level of global health emergency, its impacts are clearly very extensive, particularly for the Indonesians' social-economic perspectives, which need to be studied. This pandemic is a disaster to many parts of the world, thus its impacts on and transmission to health may worsen unemployment, poverty and inequality, thus the world, particularly Indonesia, must rise up to prepare new employments for the people's prosperity. This pandemic clearly makes it more difficult for Indonesia to settle the three main development problems.

Before the Covid-19 pandemic, there were three main problems of economic development that were very difficult for the Indonesian people to solve, namely the high problem; unemployment, poverty and income inequality. The latest data in 2019, the number of absolute unemployment in Indonesia is 7.05 million people or an increase of 3.3 percent (BPS, 2019). The poverty rate, although slightly decreasing, is still high at 24.2 percent (BPS, 2019). Based on the value of the Gini index ratio, the level of economic inequality in Indonesia at the end of 2019 is still high and is at the level of 0.382 or only down 0.002 points. When the problem of the Covid-19 disease outbreak occurs, the development problem will become increasingly difficult to solve. Novelty and the contribution of this research is that it can provide alternative new policy implications in overcoming the main development problems that have now become increasingly difficult to solve.

Entrepreneurial business opportunities will create employment which may make the economy grow and develop as the society's stable economic foundation (Prasetyo \& Kistanti, 2020; Prasetyo, 2019a; Acs et al., 2018). J.A. Schumpeter's basis of theory on entrepreneurship as the main factor to develop the economy is still relevant until now (Kadir \& Sarif, 2016; Prasetyo \& Kistanti, 2020; Prasetyo, 2019b). This means that Schumpeter's entrepreneurial theory may still be used as the basic fundamental concept in this paper regarding economic growth, entrepreneurship theory and social entrepreneurship theory, which remains appropriate to be a factor model to develop society's sustainable social-economy in Indonesia. Entrepreneurship is the driver of growth and represents innovation flow (Kadir \& Sarif, 2016; Acs et al., 2018). Meanwhile, social entrepreneurship (SE) is actually not a new phenomenon, but has grown to be an important and fashionable construction and a very relevant topic in entrepreneurial research (Nicolás et al., 2018; Drucker, 2014; Ebrashi, 2013; Tauber, 2019; Sassmannshausen \& Volkmann, 2013). Tauber (2019) has explained how social entrepreneurship contributes to the objective of sustainable development by solving society's problems and increase the impacts.

The behavior theory of social entrepreneurship learns the contextual factors leading to creation of social business, underlying organizational dynamics and structure and how this typology measures social impacts, mobilizes resources and brings sustainable social change (Ebrashi, 2013). Based on the concept above, the main problem is how social entrepreneurship factor contributes to 
creating entrepreneurial business opportunities and business competitiveness. The objective of this paper is to explain the role of fundamental social entrepreneurship in encouraging creation of entrepreneurial opportunities which may increase economic growth, competitiveness and prosperity. The urgency of this paper is that it is intended to explain the contribution of entrepreneurial culture which may help settle fundamental problems of economic development in Indonesia. The novelty and originality of this research are that it may provide an alternative to the implication of new policy to solve main development problems which are currently getting more difficult to solve.

The existing corona virus pandemic clearly makes the three main problems of economic development in Indonesia more difficult to solve, thus Jokowi administration's four track strategy; pro-growth, pro-job, pro-poor and pro-equity policies in encouraging economic growth to solve the three problems may seem to fail (Prasetyo, 2011, 2020b). The urgency and novelty of this paper are to examine the existing gap and explain the contribution of the role of social entrepreneurship in creating entrepreneurial business opportunities to encourage economic growth and business competitiveness towards common prosperity. Argumentatively, the government is required to sustainably enhance its work in a higher, quicker, more appropriate and harder manner for accurate development targets and goals towards Indonesia advancement in Indonesia golden year 2045. Therefore, it requires an entrepreneurial culture development which may encourage continuous and sustainable economic growth and competitiveness (Prasetyo, 2019b, 2020b).

Theoretical and empirical argumentation is proposed for the concept of social entrepreneurship's role in this paper to close the gap which cannot be closed or touched by public institutions (formal governmental and private institutions). Although the concept of social entrepreneurship's role is not the only one, but the presence of this social entrepreneurship ecosystem in Indonesia will be beneficial for the people's real life now and in the future. The empirical experience of the application of social entrepreneurship has been conducted to encounter the impacts of crisis in Jordan and Lebanon (Sidlo \& Al-Jafari, 2019). The result of research conducted by Sidlo \& Al-Jafari (2019) explains particularly to the segment working with refugees, of which result is relatively not developing yet, non-structured and non-organized. However, Sidlo \& Al-Jafari (2019) also explain that the potential to have positive impact is relatively clear to the life of refugees living in the two countries significantly. This experience may immediately be applied to Indonesia. If the government may significantly encourage social entrepreneurship, the government may be deemed aware of operating the most important function of government's expense to protect the Indonesians' economy, social and culture significantly.

\section{Literature Review}

The concept of entrepreneurship theory generally covers two main approaches: 
Economic theory (or Schumpeterian) and Behavioral theory (Diasa \& Tebaldib, 2012). Meanwhile, the basic concept of social entrepreneurship theory develops more as part of entrepreneurial literature (Ebrashi, 2013). Diasa \& Tebaldib (2012) explain in economic theory and argues that the essence of entrepreneurship lies on the cunning and creative competence in new business opportunities, with desire to create various usages of financial, human and material resources, and how to shift them from their traditional system. Furthermore, it is to make them a never-existing creative combination for business expansion. Meanwhile, the behavioral theory in turn deems entrepreneur as the source of formal authority, with the capability to change what is obsolete to be something modern or new (Diasa \& Tebaldib, 2012). Furthermore, the basic concept of social entrepreneurship theory develops as part of entrepreneurial literature (Ebrashi, 2013). According to Sebastian Aparicio et al. (2016), institutional and social entrepreneurship is the path towards holistic continuance.

Meanwhile, the concept of institutional entrepreneurship (IE) theory is not only an important branch of entrepreneurial research, but also closely related to social entrepreneurship (Nicolás et al., 2018). Therefore, the emergence of social entrepreneurship opportunities is mostly caused by a system vacancy, making both of them overlapping even more (Alarifi et al., 2019). Basically, the concept of social entrepreneurship is a social phenomenon which may direct individual or community to develop problem-solving capability and seek for future construction itself, namely; to produce social capital and human capital (Zarpellon, 2010). To put it simply, the concept of social entrepreneurship is relatively similar to that of business entrepreneurship, which is acknowledged as an important contributor not only to economy, but also for social prosperity (Christie \& Honig, 2006; Kadir \& Sarif, 2016).

According to Schumpeter, entrepreneurship is meant to find suitability (innovation) between the need and certain resource, or an innovation business to reach growth and pursue many opportunities (Sassmannshausen \& Volkmann, 2013). Social entrepreneurship (SE) is currently deemed as a developing field of study (Nicolás et al., 2018). Furthermore, in various researches on social entrepreneurship until now, researchers are reluctant to use entrepreneurship orientation (EO), but social entrepreneurship (SE) instead. The argument is that since many such research results do not find positive correlation between risk taking (EO) and corporate performance. In fact, economic objective is not the main priority anymore (Nicolás et al., 2018; Alarifi et al., 2019). However, they suggest further research to determine to what extent the finding may be applied to more comprehensive contexts and be extended to other business contexts. Currently, the results of literature study on social entrepreneurship have identified that social companies have distinguished themselves from business companies through their emphasis on social goals, use of social capital and creation of social values (Tauber, 2019).

Based on the many literature studies, we may explain that what differentiates 
social entrepreneurship from other entrepreneurships is its focus of objective. Most of entrepreneurial literatures focus on creation of new business to gain profit. Meanwhile, the objective of social entrepreneurship focuses more on achieving social mission, which is clearer in the context and result of social components. According to Drucker, with social entrepreneurship and social business, the social values in social entrepreneurship are more explicit and centralized (Ebrashi, 2013; Sassmannshausen \& Volkmann, 2013). Therefore, the urgency of social entrepreneurship's current function is expected to achieve maturity and become an interesting research topic, since the pattern of meaning in the literature of social entrepreneurship is an important research platform (Hill et al., 2010).

Furthermore, the latest literature study finds that social entrepreneurship develops more rapidly and much practices in developing countries which are commonly known as BRIICS, namely; Brazil, Russia, India, Indonesia, China and South Africa (Sengupta \& Sahay, 2018). The latest research result which widens the entrepreneurial orientation (EO) theory in the context of social entrepreneurship (SE) with a model to introduce corporate performance as a construction to examine social company has been conducted by Ghadah Alarifi et al. (2019). The result of research with 303 empirical data of social companies in Saudi Arabia shows that innovation may be proactive, but does not result in risk, and is positively closely related to corporate performance (Alarifi et al., 2019). The research conducted by Ghadah Alarifi et al. (2019) also finds that EO may still be used as a mechanism to solve constraints caused by limited resources in an environment where new opportunities rarely exist.

\section{Research Method}

This quantitative descriptive research explained the important role of social entrepreneurship factor to encourage entrepreneurial business opportunities and competitiveness towards common prosperity. From the perspective of the research objective and the need for data, this research was classified as a quantitative fundamental research. The main source of data for the purpose of this analysis was primary data obtained from local wisdom based home entrepreneurial business (micro, small and medium sized enterprise/MSME). The research population of respondent home businesses was derived from Central Java and DIY provinces with the basic characteristics of creativity, local wisdom and innovation, such as start-up business and folk handicraft business. The population was derived using the random sampling of cluster model by regency, and there were 16 chosen regencies, which were sampled based on the characteristics. Based on the criteria of population, samples were taken with a stratified random sampling technique, resulting in 125 home entrepreneurial businesses deemed representative. Characteristics of the sample in general are special characteristics in the population namely; creative, innovative, has local wisdom, a strong spirit, has little capital and is easy to emulate.

The variable measuring dimension in this paper was the Gini index/ratio 
model of which general formula was renowned to researchers and readers, thus it was unnecessary to rewrite it here. The argument is that the general basic formula of IG values is simple, useful and widely known. The formula is as follows; $I G x=1-\sum_{i=1}^{n} f i\left(Y_{i}-Y_{i-1}\right)$.

It was then followed with a model path analysis of correlational recursive collaboration. The concerned correlational collaboration was between the main resource factors, namely human capital (HC) and social entrepreneurship. The argumentation is that developing entrepreneurial business opportunities which may generate economic and social values requires the concept of social entrepreneurship (SE), which requires different configuration of human resources from commercial entrepreneurship in this paper. In the pattern of model, the concerned collaboration between human capital and social entrepreneurship is symbolized with a correlation model (rHC.rSE).

For ease of understanding, the model was arranged into a functional equation before the path analysis method is used. The basic model of structural mathematic equation of path analysis method as referred to in this paper may be arranged as follows.

$$
\begin{gathered}
Y_{i}=\rho Y_{i} \cdot X_{1}+\rho Y_{i} \cdot X_{2}+\rho Y_{i} \cdot X_{3}+\varepsilon_{1} \\
Z_{i}=\rho Z_{i} \cdot X_{1}+\rho Z_{i} \cdot X_{2}+\rho Z_{i} \cdot X_{3}+\rho Z_{i} \cdot Y_{i}+\varepsilon_{2}
\end{gathered}
$$

where: $Y_{i}$ meant the entrepreneurial business opportunities variable, $X_{1}$ meant human capital, $X_{2}$ meant social entrepreneurship, $X_{3}$ meant new product and $Z_{i}$ meant entrepreneurial business competitiveness. Meanwhile, the $\rho$ parameter value of path analysis and $\varepsilon_{1}$ dan $\varepsilon_{2}$ were random residue in each of the equation. Furthermore, based on the basic model of equation, we may describe the path analysis of multiple-path correlation model as in Figure 1. Basically, there were three basic models of generally known path analysis: 1) correlation model, 2) mediation model, and 3) independent model. The argumentation for selection and use of path analysis of correlation model (correlated path model) was to

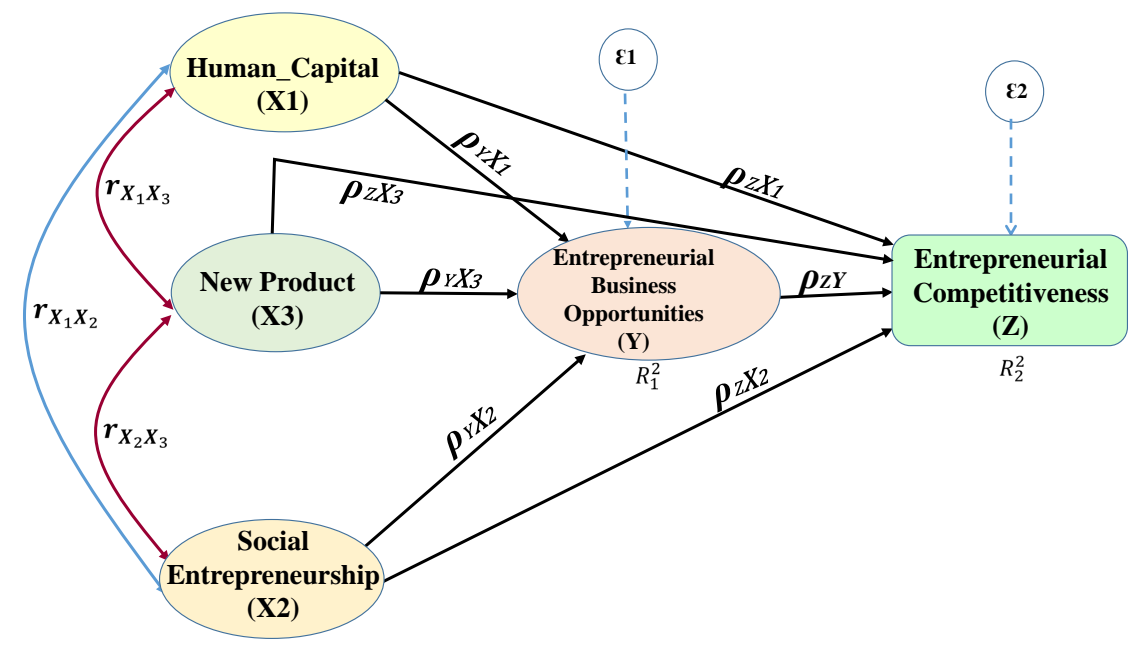

Figure 1. Diagram of correlated recursive multiple path model analysis. 
view the role of correlation between human capital and social entrepreneurship variables as intended by this paper's objective. Meanwhile, the argumentation of use of recursive model was for ease of understanding, since recursive model explains that such correlation was one way, instead of the contrary.

\section{Result and Discussion}

The Covid-19 pandemic influences multi-sectors quite extensively in Indonesia, thus any transmission of policy made from the health sector is also correlated with that of other sectors including; institutional politics, education, social, economy, culture, etc. The Indonesian Government has publicly attempted hard and the best it can do. However, it is quite likely that not all problems may be solved well and completely. Therefore, the role of social entrepreneurship may help explain the role which cannot be settled by general public policy. The impacts of Covid-19 pandemic, particularly on the economy and social, are quite serious with its domino effect, especially regarding policies of solving social-economic development problems, which get more difficult to settle. The government's current policies which are made to encourage economic growth and reduce the problems of unemployment, poverty and unequal income as well as other social-economic problems in the short course may fail (Prasetyo \& Kistanti, 2020), for example, when the investment sector as the main driver of economic growth declines during economic recession resulting from the Covid-19 pandemic, which will have multi-dimension and multi-sector impacts. One of which from the social-economic perspectives is increased unemployment, either directly as the result of termination of employment or indirectly as the result of no new investment and declining economic growth. The impact of such great number of unemployment will lead to worsened poverty and bigger inequality, which will be more difficult to solve.

The main development problems are generally difficult for the government to solve with public policies. Therefore, one of the best solutions offered by this paper is to strengthen the development of social entrepreneurship culture (social entrepreneurship) for all Indonesians. Indonesia must immediately rise up by building and strengthening social entrepreneurship and new institutionalization capitals as one solution to help solve problems which generally cannot be solved with formal governmental and private public policies. When the formal public policies are supported with strengthening of social entrepreneurship capital development as the main driver of entrepreneurship, it is expected that common prosperity will be more easily realized and experienced by the Indonesians more fairly, evenly and significantly. In fact, problems of social entrepreneurship are not something new in Indonesia which is much based on social capital, thus it is easier to do. Globally, social entrepreneurship problems have been popularized by Dr. Muhammad Yunus, a renowned figure who founded Garmeen Bank in Bangladesh. The example of social entrepreneurship applications in other places have been made in Yordania and Lebanon (Sidlo \& Al-Jafari, 2019). 
In this occasion, this paper attempts to explain and propose to pay more attention to and do the same thing. Although the role of social entrepreneurship is not maximal yet and not the only and the best solution, but it may at least help cover the weaknesses of public policies which have been, are currently and will be made by governmental and private institutions, since this social entrepreneurship intends to cover the gap which cannot be or has not been covered by governmental and private public institutions in general since this social entrepreneurship is focused more on solving the main economic problems as well as public social-economic problems. The social entrepreneurship will help present the best positive impacts, particularly through better entrepreneurial opportunities and enhanced competitiveness. Based on the research result, the problems may be explained better.

The result of research in Table 1 may be taken as the strong argumentation to explain the general description above. Based on Table 1, in the model-1 there is standardized coefficient value. Based on the standard coefficient value, it is clear that social entrepreneurship factor may give the biggest contribution positively and significantly of 0.569 or 56.9 percent to creation of entrepreneurial business opportunities in crisis like Covid-19 pandemic. This means that the contribution is important to encourage creation of the existing and new social entrepreneurial business opportunities to help solve economic development problems. Furthermore, the core factor as the main determinant of human capital remains high of 35.6 percent, and positively and significantly influences the creation of entrepreneurial business opportunities in the research area. In case of collaboration of the two factors, human capital and social capital, directly, indirectly or totally, it

Table 1. Output of regression model path analysis on entrepreneurial opportunities and competitiveness.

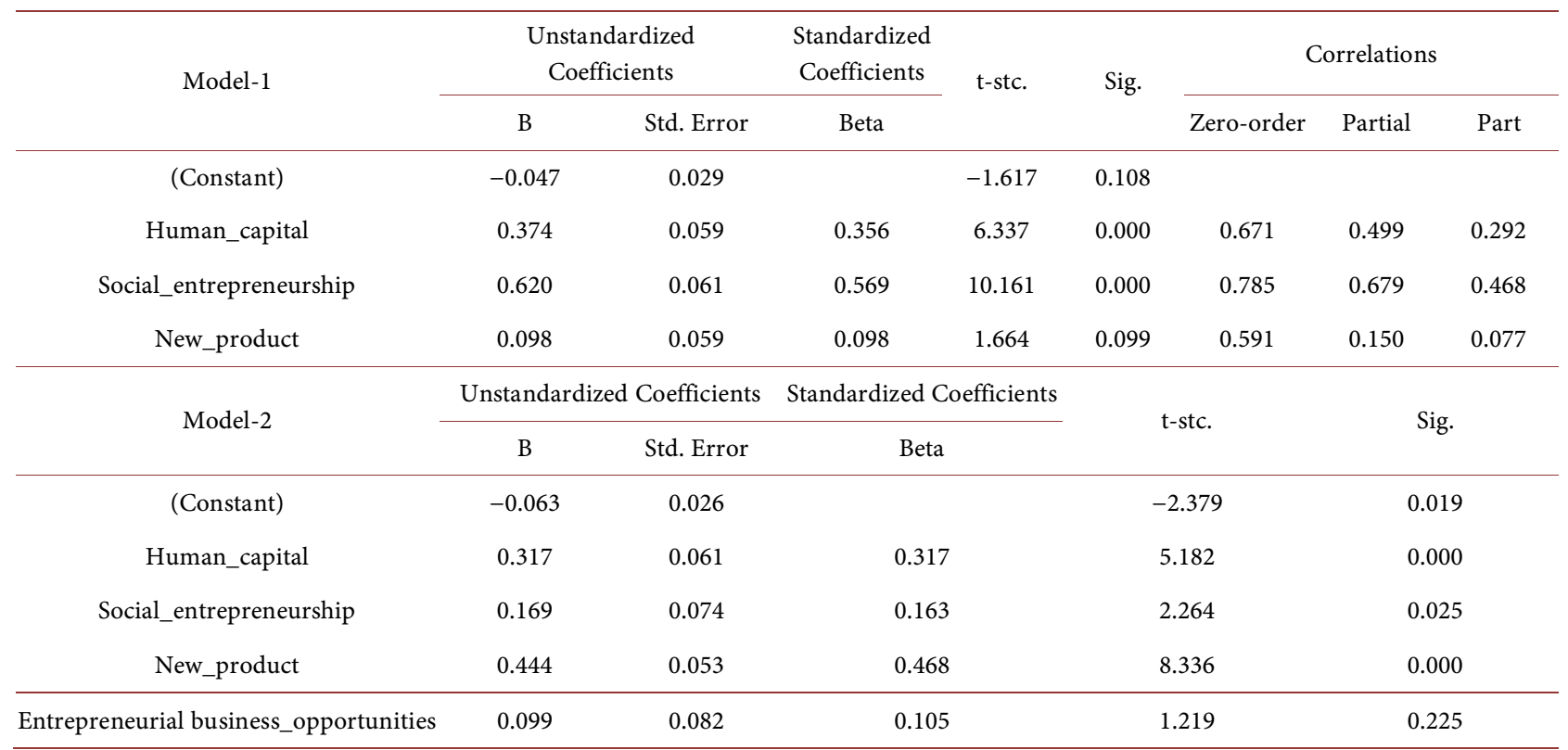

Model-1: Dependent Variable: Entrepreneurial Business Opportunities $\left(Y_{i}\right)$; Model-2: Dependent Variable: Entrepreneurial Business Competitiveness $\left(Z_{i}\right)$. Source: processed primary data. 
will contribute more to the creation of new and existing entrepreneurial business opportunities. Meanwhile, in the early formation of model, that the contribution of the role of new product factor is small is reasonable and normal, both theoretically and empirically. In the next stage, the role of new product factor will contribute the most to developing entrepreneurial competitiveness.

Furthermore, based on the research results in Table 1 with model-2, it is evident that new product factor contributes most dominantly to creation of entrepreneurial business competitiveness of 46.8 percent. It is quite important to understand this research result, both theoretically and empirically, that the key to good business competitiveness is the extent of product's contribution, in which the extent of product is derived from entrepreneurial business opportunities driven by the contribution of the main factor of social entrepreneurship's role. In other words, continuous and sustainable entrepreneurial business competitiveness may be achieved more easily through the opportunities of creation of new products generated by entrepreneurial businesses driven by main resource factor of social entrepreneurship. Although in the model-2 the direct role and contribution of social entrepreneurship factor slightly decline compared to that of model-1, but it still plays positive and significant role in helping to improve business competitiveness. In addition, the total influence of social entrepreneurship's role factor is till big, positive and significant on entrepreneurial business competitiveness. For more clarity, this explanation may be observed in Figure 2, model of diagram of the result of path analysis.

Meanwhile, in model-2 it is evident that the role of entrepreneurial opportunities is positive, but not significant. By ecosystem, the social entrepreneurship in Indonesia is still small and weak. However, its development function and contribution are important and positive to the society's life and competitiveness and keep strengthening. Therefore, it is clear and we must aware that the potential to have positive impact in the society's life may increase and become more significant, although at the early formation of role and function it is not well structured

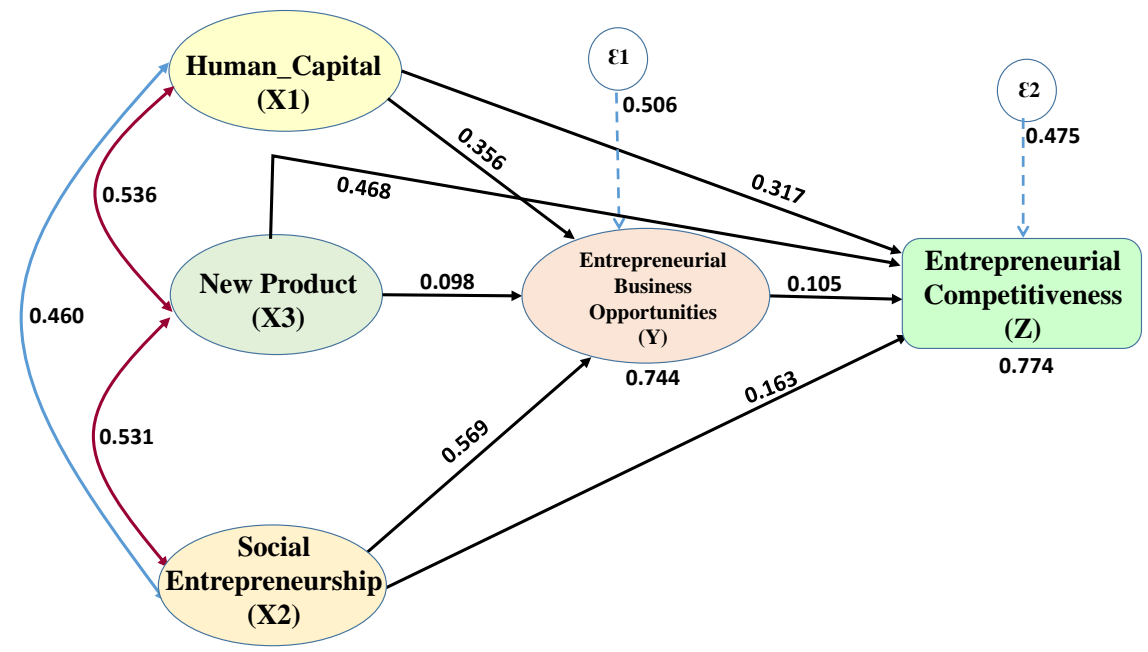

Figure 2. Model of diagram of the result of correlated recursive multiple path analysis. 
and organized. This phenomenon is reasonable, which means that the low contribution is also reasonable when so far the role of social entrepreneurship and entrepreneurial opportunities are not excellent or not the only and main solution to improving prosperity and competitiveness. However, the most important is the people's social-economic togetherness in improving their common competitiveness and prosperity sustainably now and in the future. This means that even if it is small, the real and positive benefit may be enjoyed by the society more quickly.

The model of diagram of the result of path analysis in Figure 2 confirms and clarifies the explanation above. In the diagram, it is evident that the direct role improves the entrepreneurial business competitiveness which is driven by new product role the most. However, in the beginning of entrepreneurial opportunities, the role of new product is the smallest. This is reasonable, since the emergence of entrepreneurial business opportunities is driven by social entrepreneurship factor and collaboration between human capital and social entrepreneurship factors. This means that the basic idea of emergence of entrepreneurial intention and opportunities is because of society's social-economic problems that they want to solve their own problems, either in family or society group. The research result explains that in the beginning there are family members with skills and creativities in the society who creatively and innovatively create new business opportunities, which then lead to creation of shared business opportunities which may reduce unemployment ("Schumpeter" effect). On the other hand, this research result also finds that since there is unemployment in the society, creative and innovative ideas start to exist to open new business opportunities ("refugee" effect). Therefore, this research result supports the economic development theory through J.A. Schumpeter's entrepreneurial innovation, either the "Schumpeter" effect or "refugee" effect, which means that the J.A. Schumpeter's basic theory remains applicable to the empirical case in Indonesia.

However, this research result is generally deemed ambiguous and difficultly confirms which effect is bigger and more significant for certain. This research result specifically implies that entrepreneurial business group in the form of handicraft and start-up businesses tend to be bigger because of the driving effect. Meanwhile, other types of entrepreneurial businesses may exist mostly because of the Schumpeter effect. The most important critical note in this research is that the two effects mutually, positively drive society's social-economy, since in the field, it is quite difficult to determine such certain difference. For example, there is no convention and certainty in various latest research results regarding this cause-effect (Langroodi, 2017; Mathilde Aubry \& Renou-Maissant, 2015; Prasetyo et al., 2019; Rico \& Cabrer-Borrás, 2019). However, one latest research result specifically, expressly states that the positive impact of economic cycle on business creation shows driving effect, showing that unemployment stimulates creation of business (Rico \& Cabrer-Borrás, 2019). In addition, the result of research conducted by Apaydin (2018) states that regarding the causality between 
employment and entrepreneurship Turki, the Schumpeter effect is declared valid and driving effect (refugee effect) is invalid. Based on the two research results, we may state that creativity and innovation factors are the main determining and first factors to realize entrepreneurship.

With regard to this paper, that the other critical analysis related to the research result states that the Schumpeter effect is stronger and more valid than the refugee effect confirms this paper's argumentation, that the emergence of many entrepreneurial business opportunities may improve competitiveness and prosperity by preventing unemployment (Prasetyo, 2020a). This means that the human capital is the main determining factor in the entrepreneurship. In other words, we may state that it is better to prevent unemployment that to remedy it, even if the reverse effect may also be declared good. However, it is better to prevent unemployment than to reduce existing unemployment. Therefore, it is better to strengthen the development of entrepreneurial business opportunities creation culture since the beginning as a condition of prosperity instead of merely solving existing unemployment problem.

Furthermore, the research result in Table 2 explains that the total influence of human capital, social entrepreneurship and new product resource factors on entrepreneurial competitiveness, directly and indirectly, through business opportunities is relatively low of only 48.7 percent. However, it is interesting to note that the extent of role of new product factor $\left(X_{3}\right)$ contributes the most, directly and in total influence. Meanwhile, the extent of influence of social entrepreneurship factor $\left(X_{2}\right)$ seems to be contributed by indirect more than indirect influence. This shows that the new social entrepreneurship factor may directly contribute the most only to the factor of openness of new entrepreneurial business. However, it is still "small", so that the role of entrepreneurial business opportunities is positive but insignificant to business competitiveness, which also makes the role of social entrepreneur not maximal. Furthermore, the role of human capital factor $\left(X_{1}\right)$ remains the main determining factor to influence business opportunities and entrepreneurial business competitiveness, thus this research is still consistent to previous research (Prasetyo \& Kistanti, 2020; Prasetyo, 2020a).

Table 2. Result of direct influence, indirect influence and total influence of business opportunities resource factor on entrepreneurial business competitiveness.

\begin{tabular}{|c|c|c|c|c|c|c|c|}
\hline \multirow{2}{*}{ Variable } & \multirow{2}{*}{$\begin{array}{c}\text { Direct } \\
\text { Influence }\end{array}$} & \multicolumn{5}{|c|}{ Indirect Influence } & \multirow{2}{*}{$\begin{array}{c}\text { Total } \\
\text { Influence }\end{array}$} \\
\hline & & $\operatorname{HC}\left(X_{1}\right)$ & $\operatorname{SE}\left(X_{2}\right)$ & $\operatorname{NP}\left(X_{3}\right)$ & Y (PUK) & Sub Total & \\
\hline $\mathrm{HC}\left(X_{1}\right)$ & 0.100 & & 0.024 & 0.006 & 0.012 & 0.042 & 0.142 \\
\hline $\operatorname{SE}\left(X_{2}\right)$ & 0.027 & 0.024 & & 0.003 & 0.010 & 0.037 & 0.064 \\
\hline $\operatorname{NP}\left(X_{3}\right)$ & 0.219 & 0.006 & 0.003 & & 0.010 & 0.019 & 0.238 \\
\hline$Y_{i}(\mathrm{PUK})$ & 0.011 & 0.012 & 0.010 & 0.010 & & 0.032 & 0.043 \\
\hline Total & 0.357 & & & & & 0.130 & 0.487 \\
\hline
\end{tabular}

Source: processed primary data. 
Basically, that the contribution of resource factors to competitiveness is still small is caused by low direct role of entrepreneurial business in business competitiveness. However, this phenomenon is reasonable and normal as an initial fundamental research, thus a more extensive and comprehensive is still needed to measure competitive and comparative competitiveness.

\section{Conclusion and Recommendation}

The important role of social entrepreneurship factor's contribution to encouraging entrepreneurial business opportunities is dominant, positive and significant. However, the role of entrepreneurial business opportunities is, despite positive, insignificant in entrepreneurial business competitiveness, thus the role of social entrepreneurship factor's contribution, despite positive and significant, directly, indirectly and totally, is also still small. The interesting conclusion of this research result is that entrepreneurial business opportunities driven by collaboration between human capital and social entrepreneurship have Schumpeter's drawing effect (Schumpeter effect) and driving effect (refugee effect), although its role is specifically bigger than the drawing effect, thus the emergence of entrepreneurial business opportunities is better to solve unemployment instead of reducing unemployment.

Therefore, the implication of recommended policy is that, it should perform economic regulation policy since the beginning and as early as possible to strengthen the potential of development of new entrepreneurial business opportunities creation culture as the most important condition of common prosperity instead of only serving only as a method to solve unemployment, since preventing unemployment is better and more important than solving unemployment. This means that even if social entrepreneurship is not the only and the best solution, it may present the best result to prevent unemployment and serve as the best supplement to public policy strategy. However, this empirical research is geographically, economically limited in scope, thus further research is recommended with a more extensive and comprehensive capacity and regarding comparative and competitive competitiveness to compare with and strengthen the results of this research.

\section{Acknowledgements}

The researcher would like to express his gratitude to DRPM of Directorate General of Higher Education that has supported and funded this research through the research scheme of Decentralization of PDUPT from the fund of DRPM of Directorate General of Higher Education, Ministry of Research and Higher Education, Indonesia with Contract Letter: No.056/SP2H/LT/DRPM/2020.

\section{Conflicts of Interest}

The authors declare no conflicts of interest regarding the publication of this paper. 


\section{References}

Acs, Z. J., Estrin, S., \& Mickiewicz, T. (2018). Entrepreneurship, Institutional Economics, and Economic Growth: An Ecosystem Perspective. Small Business Economics, 51, 501-514. https://doi.org/10.1007/s11187-018-0013-9

Alarifi, G., Robson, P. J. A., \& Kromidha, E. (2019). The Manifestation of Entrepreneurial Orientation in the Social Entrepreneurship Context. Journal of Social Entrepreneurship, 10, 307-327. https://doi.org/10.1080/19420676.2018.1541015

Aparicio, S., Urbano, D., \& Audretsch, D. (2016). Institutional Factors, Opportunity Entrepreneurship and Economic Growth: Panel Data Evidence. Technological Forecasting and Social Change, 102, 45-61. https://doi.org/10.1016/j.techfore.2015.04.006

Apaydın, Ş. (2018). The Relations between Unemployment and Entrepreneurship in Turkey: Schumpeter or Refugee Effect? Fiscaoeconomia, 2, 1-14. https://doi.org/10.25295/fsecon.2018.02.001

BPS (Badan Pusat Statistik) (2019). Statistical Yearbook of Indonesia. Nomor Publikasi: 03220.1911.

Christie, M. J., \& Honig, B. (2006). Social Entreprenuership: New Research Findings. Journal of World Business, 41, 1-5. https://doi.org/10.1016/j.jwb.2005.10.003

Diasa, J., \& Tebaldib, E. (2012). Institutions, Human Capital, and Growth: The Institutional Mechanism. Structural Change and Economic Dynamic, 23, 300-312. https://doi.org/10.1016/j.strueco.2012.04.003

Drucker, P. F. (2014). Innovation and Entrepreneurship Practice and Principles. New York: HarperCollins Publishers, Inc.

Ebrashi, R. E. (2013). Social Entrepreneurship Theory and Sustainable Social Impact. Social Responsibility Journal, 9, 188-209. https://doi.org/10.1108/SRJ-07-2011-0013

Hill, T. L., Kothari, T. H., \& Shea, M. (2010). Patterns of Meaning in the Social Entrepreneurship Literature: A Research Platform. Journal of Social Entrepreneurship, 1, 5-31. https://doi.org/10.1080/19420670903442079

Kadir, M. A. B. A., \& Sarif, S. M. (2016). Social Entrepreneurship, Social Entrepreneur and Social Enterprise: A Review of Concepts, Definitions and Development in Malaysia. Journal of Emerging Economies and Islamic Research, 4, 1-16.

Langroodi, F. E. (2017). Schumpeter's Theory of Economic Development: A Study of the Creative Destruction and Entrepreneurship Effects on the Economic Growth.

Mathilde Aubry, J. B., \& Renou-Maissant, P. (2015). Entrepreneurship and the Business Cycle: The "Schumpeter" Effect versus the "Refugee" Effect-A French Appraisal Based on Regional Data. The Annals of Regional Science, 54, 23-55. https://doi.org/10.1007/s00168-014-0645-x

Nicolás, C., Rubio, A., \& Fernández-Laviada, A. (2018). Cognitive Determinants of Social Entrepreneurship: Variations According to the Degree of Economic Development. Journal of Social Entrepreneurship, 9, 154-168. https://doi.org/10.1080/19420676.2018.1452280

Prasetyo, E. (2011). Deindustrialisasi Sebuah Ancaman Kegagalan Triple Track Strategy Pembangunan di Indonesia. JEJAK: Jurnal Ekonomi Dan Kebijakan, 4, 3.

Prasetyo, E. (2019a). The Reliability of Entrepreneurial Productivity as Driver of Economic Growth and Employment. International Journal of Entrepreneurship, 23, 1-15.

Prasetyo, E. (2019b). Role of Entrepreneurial Culture as the Driver of Economic Growth. International Journal of Economics and Financial Issues, 9, 237-243. https://doi.org/10.32479/ijefi.7882 
Prasetyo, E. (2020a). Human Capital as the Main Determinant of Regional Economic Growth. International Journal of Advanced Science and Technology, 29, 6261-6267.

Prasetyo, E. (2020b). Peran Strategis Kewirausahaan Dalam Mendukung Kebijakan Four Track Strategy di Indonesia. Jurnal Ekonomi dan Pembangunan Optimum, 10, 1-15.

Prasetyo, E., \& Kistanti, N. R. (2020). Human Capital, Institutional Economics and Entrepreneurship as a Driver for Quality \& Sustainable Economic Growth. Entrepreneurship and Sustainability Issues, 7, 2575-2589.

Prasetyo, E., Setyadharma, A., \& Kistanti, N. R. (2019). The Relationship between Institutions and Business Opportunities toward Economic Growth. Economics Development Analysis Journal, 8, 281-291. https://doi.org/10.15294/edaj.v8i4.36311

Rico, P., \& Cabrer-Borrás, B. (2019). Entrepreneurial Capital and Productive Efficiency: The Case of the Spanish Regions. Technological and Economic Development of Economy, 25, 1363-1379. https://doi.org/10.3846/tede.2019.10549

Sassmannshausen, S. P., \& Volkmann, C. (2013). A Bibliometric Based Review on Social Entrepreneurship and Its Establishment as a Field of Research. Schumpeter Discussion Paper 2013-003.

Sengupta, S., \& Sahay, A. (2018). Social Enterprises in the Indian Context: Conceptualizing through Qualitative Lens. Journal of Global Entrepreneurship Research, 8, Article No. 1. https://doi.org/10.1186/s40497-018-0087-5

Sidlo, K., \& Al-Jafari, M. (2019). Social Entrepreneurs' Responses to the Refugee Crisis in Jordan and Lebanon. Paper Presented at the Femise.

Tauber, L. (2019). Beyond Homogeneity: Redefining Social Entrepreneurship in Authoritarian Contexts. Journal of Social Entrepreneurship. https://doi.org/10.1080/19420676.2019.1668829

Zarpellon, S. C. (2010). O empreendedorismo e a teoria econômica institucional. Revista Iberoamericana de Ciências Empresariais y Economia, 1, 47-55. 